\title{
ВАРШАВА В ЖИТТІ І ТВОРЧОСТІ ГАННИ БАРВІНОК
}

\author{
Тетяна Олещенко \\ Міжрегіональна академія управління персоналом, Київ, Україна \\ ORCID: 0000-0002-2115-4979
}

Резюме: Ганна Барвінок (Олександра Михайлівна Білозерська-Куліш, 1828-1911) одна 3 найперших письменниць-жінок в українській літературі. Про свою першість вона може посперечатись із самою Марко Вовчок, яку традиційно прийнято вважати першою українською жінкою-письменницею. Свого часу Ганна Барвінок була широко відомою і знаною, а сьогодні ії творчості приділяється значно менше уваги, ніж вона на то заслуговує.

Перебуваючи в тіні слави свого відомого і шанованого всіма чоловіка Пантелеймона Куліша, ставши для нього не тільки дружиною, а й вірним другом, помічником і однодумцем, тоді ще Олександра Куліш не приділяла уваги своєму літературному таланту. Лише прагнення допомагати й бути достойної свого видатного чоловіка штовхали іiі до літературної діяльності.

Для Олександри Куліш знаковим містом стала Варшава. Дорога до Варшави, перебування у Варшаві в товаристві Куліша і його оточення стали шляхом в українську літературу для Олександри Куліш, перетворивши ії на жінку-першопрохідця і новатора - Ганну Барвінок.

Ганна Барвінок стає основоположницею нового напрямку в українській літературі - етнографічного реалізму. Виконуючи настанови чоловіка і записуючи все, що бачить дорогою з Чернігівщини до Варшави, вона жваво описувала реалії тогочасного життя, збираючи матеріал для своїх перших оповідань. Безумовно, культурне середовище, в якому перебувала Ганна Барвінок, польське оточення рідного брата і чоловіка не могли не вплинути на письменницю-початківця. Варшава не тільки надихнула писати, а і докорінно змінила життя самої Ганни Барвінок. Проте зв'язки Ганни Барвінок $з$ польським культурним середовищем не обмежувалися лише перебуванням певний час у певному географічному просторі. Вони формувалися завдяки Кулішу і через його посередництво.

Ганна Барвінок все життя повторювала, що лише "записує 3 народних уст”, як навчив їі чоловік - П. Куліш. Лише об'єктивні обставини (арешт Куліша, переживання за його долю, заслання до Тули, куди вона поїхала за чоловіком) затримали появу в українській літературі нового імені - Ганни Барвінок.

Ключові слова: Ганна Барвінок, Пантелеймон Куліш, польські культурні зв'язки, етнографічний реалізм, українська література, засновник. 
Ганна Барвінок (Олександра Михайлівна Білозерська-Куліш, 1828 $1911)$ - одна із найперших письменниць-жінок в українській літературі. Вона поклала початок жіночій літературі, яка пізніше посприяла появі феміністичного руху (хоча сама Ганна Барвінок була далека від фемінізму). 3'явилися такі імена як Марко Вовчок (Марія Вілінська), Олена Пчілка (Ольга Косач), Марія Загірня (Марія Грінченко), Леся Українка (Лариса Косач-Квітка), Наталія Кобринська, Ольга Кобилянська, Климентина Попович, Свгенія Ярошинська, Уляна Кравченко (Юлія Шнайдер), Катря Гриневичева (Катерина Гриневич) та інші.

Свого часу Ганна Барвінок була широко відомою, а сьогодні, на жаль, iї творчості приділяється значно менше уваги, ніж вона заслуговує. У радянські часи була замовчувана: українська етнографія була знищена як буржуазно-націоналістична наука, а вона - творець етнографічної прози і сама етнограф і фольклорист. Не пройшла відбору в радянську літературу за ідеологічними критеріями: вона сповідувала ліберальні патріотичні погляди.

Подорож до Варшави стала доленосною для Олександри Куліш-Білозерської - вона почала писати. У спогадах письменниця згадує, що одразу по від'їзді із Києва чоловік дав їй “зшиток і олівець”, щоб вона записувала все, що почує чи побачить ${ }^{1}$. Цих Кулішевих настанов Ганна Барвінок дотримувалася все життя - записувала із народних уст. І в листуванні з Борисом Грінченком вона наголошувала на тому, що Куліш був iii учителем і саме завдяки йому сформувалася як письменниця. У листі до Бориса Грінченка (весна 1900 року) Олександра Куліш писала:

Се ж не я, а моя дружина росте угору. Що мав силу создать - впихнуть мені трохи своєї душі і високого почуття до свого рідного. Я радію, що оправдала його надії².

Пантелеймон Куліш всіляко підтримував іiі. “...Моя неоцінна дружина і поощряла, кажучи, що довіку будеш «зелененьким барвіночком»”, - писала Ганна Барвінок Борису Грінченку у листі від 11 травня 1900 року³.

Це буде пізніше. А тоді молоденька Олександра Білозерська-Куліш (майбутня Ганна Барвінок) відчувала сумніви, невпевненість у собі, у своїх літературних здібностях, у своїх знаннях, не розуміла, що і як треба записувати. У своїх спогадах Ганна Барвінок, згадуючи свій тодішній психологічний стан, пише:

Г. Барвінок, Приїзд до Києва на перепутті до Вариави, "Українська хата" 1911, Липень-серпень, с. 305.

2 Лист до Б. Д. Грінченка (кінець березня - початок квітня 1900 року), ІР НБУВ, ф. III, № 38094.

3 Лист до Б. Д. Грінченка від 11 травня 1900 року, ІР НБУВ, ф. III, № 38100. 
I праця гнітила мене. Не берусь я за олівець! Але ж надужити увагу і прихильність до мене Куліша, не уважити таке неухильне прохання, і уперте, тверде слово його, того чоловіка, перед котрим я завжди бажала б бути найлучшою, як найяскравішою, поважнішою, мучило мене. Перемогти у собі гонор самолюбства та йти під впливом дужчого треба було, хоч і бувши дуже скромною, невпевненою в собі, не признаваючи за собою ні літературних здібностей, ніяких знаній, освіти, а головне те, що я нічого і не вбачала перед собою такого, щоб мене особисто вразило».

У той час вона створила своєрідний культ із образу свого чоловіка. Куліш був їі кумиром, символом поклоніння, тому вона не могла і не хотіла його розчарувати і ухилитися від його завдання.

Несподівано знайшлася і тема для записів. Подорожуючи, молоде подружжя потрапило у негоду і змушене було зупинитися у корчмі. Там Олександра Куліш побачила слугу Остапа:

У кімнату до нас, серед сього урагану, з'являється тихая, як голубка, замучена постать, хоч і зброя у неї мужествена. 3 боку висів на ремні великий у ножнах ніж, як у гайдамаки: сам коренастий, середнього зросту. Його убрання зовсім не стосується до першого мого враження. При сьому на йому свитина внизу та постоли, з котрих стирчить солома, i чвакають вони 3 якимсь свистом та зоставляють болотяні калюжі сліду 5 .

\section{Ця зустріч справила величезне враження на Ганну Барвінок:}

Се душу мою вражає. Я таких ще по хуторах в кріпацтві не вбачала і убогих; і душа моя загорілась особливим жалем спочування і нахилила мене до його. Я хочу сю голубицю принадить до себе та втягнути ії в дружні розмови зо мною. В сьому, мов тихому кволому серці, таївся цілий ад, який зібрався 3 різних джерел - кривд людських, людожерів та жовчі. Нещаслива його доля! Мені вдалось зробити дещо для його - полегшити його убогу душу гарячим співчуванням...» ${ }^{6}$.

Це стало поштовхом для початку іiі літературної творчості:

От коли перо моє вперше гірку долю намалювало; звідкіль я ії̈ зрозуміла? Бо до того часу я такої на людях не виділа й не чувала. Може того вперше й не квапилась писати, ще дуже молода була. А се сама доля моя, мабуть, про мене піклувалась і підготовляла мене ще й до гіршого в моїм житті несподіваного» ${ }^{7}$.

4 Г. Барвінок Приїзд до Києва на перепутmі до Варшави, “Українська хата” 1911, Липень-серпень, с. 305.

5 Там само, с. 307.

6 Там само.

7 Там само. 
3'явилася тема, яку Олександра Куліш довго шукала і нарешті знайшла. Свої записи вона показала чоловікові і братові. Вони порадили їй “не кидати пера".

Подорожні враження 1847 року лягли в основу першого оповідання Ганни Барвінок. Це оповідання мало два варіанти. Перший варіант - нарис C Вольыни - надрукований в журналі “Основа" за січень 1861 року за підписом “Анна Барвинок” (без вказівки дати написання). Він надрукований російською мовою, а діалоги - українською. Борис Грінченко у виданні творів Ганни Барвінок Оповідання з народних уст (Київ, 1902) помістив другий варіант під назвою Жидівський кріпак, який був повністю перекладений українською мовою, і поставив дату публікації, як дату написання оповідання. В листі до Б. Грінченка від 12 липня 1900 року вона пише: "«Жидівський кріпак» повинен бути «З Волині»" .

Нарис C Вольни повніший за оповідання Жидівський кріпак. Там, крім епізоду з кріпаком Остапом, є ще опис Рудненської станції, Житомира і Новоград-Волинська, де Ганна Барвінок зупинялася в 1847 році під час подорожі до Варшави.

Під'їжджаючи до Новоград-Волинського, Олександра Куліш перебувала у піднесеному настрої. Але настрій ії несподівано кардинально помінявся. Не маючи змоги переїхати через річку, мандрівники змушені були зупинитися на ночівлю у корчмі. Там вони і побачили Остапа, вигляд якого боляче вразив Олександру. А найбільше іiі вразило усвідомлення того, що такий Остап не один, що їх дуже багато. Усвідомлення всього побаченого і почутого спершу породжує думку: "Не лучше ли было бы нам и не знать о твоем существовании?" "10. А вже потім це враження вилилось у літературну творчість.

Образ кріпака Остапа, якого пан віддав служити євреєві-корчмареві, що знущається 3 нього, - перший яскравий трагічний образ у творчості Ганни Барвінок. Пізніше таких образів буде багато. Найчастіше це жінки. Вони часто потерпають від домашнього насильства, п'янства чоловіка (Параска Духанівна із Хатнього лиха (1861), Стеха із П'янииі, 1887). Як правило, причиною недолі жінки стають соціальні фактори (Оленка із Русалки (1889), Степанида із Нещасливої долі, 1902) тощо. Деякі з них, борючись 3 обставинами, все-таки здобувають кращу долю (Королівщи$н a$, (1896). Недаремно Борис Грінченко назвав Ганну Барвінок “поетом жіночого горя"

Там само.

Лист до Б. Д. Грінченка від 12 липня 1900 року, ІР НБУВ, ф. ІІІ, № 38107.

А. Барвинок, С Вольни, “Основа” 1861, Январь, с. 283-292; с. 292.

Б. Грінченко, Поет жіночого горя О. М. Кулішева [в:] Г. Барвінок, Збірник. До 170-річчя від дня народження, ред. В. Шендеровський, Київ 2001, с. 374-388. 
Таким чином, дорогою до Варшави Олександра Куліш почала формуватися як письменниця етнографічного напряму і стилю. Все життя вона говорила, що лише “записує з народних уст”, як вчив ії чоловік - Пантелеймон Куліш.

Приїхавши у Варшаву, молоде подружжя прожило там місяць. У Варшаві родина Кулішів контактувала з різними культурними і освіченими людьми, серед яких був і польський історик, автор праць Iсторія слов'янського законодавства (Historyia prawodawstw stowiańskich, 1832-1835), Польща і Русь до першої половини XVII cm. (Polska i Ruś aż do pierwszej połowy XVII wieku, 1842), Первісна історія Польщі і Литви (Pierwotne dzieje Polski i Litwy, 1846), професор Вацлав Олександр Мацейовський (1793-1883). Перебування Кулішів у Варшаві завершилося арештом Пантелеймона Куліша.

Вдруге Ганна Барвінок побувала у Варшаві, коли Куліш в 1864-1868 роках займав посаду Директора духовних справ і члена Комісії для перекладу російською мовою польських законів. 3 огляду на посаду, яку обіймав, Пантелеймон. Куліш сприяв провадженню царської політики. Це викликало критику з боку як польських, так і українських культурних діячів.

У листі від 15 серпня 1867 року до Матвія Симонова (Номиса), другого чоловіка Надії Білозерської, сестри Олександри Михайлівни, Пантелеймон Куліш пише:

Гавкали на мене собаки здорово, та розумний дідусь-намісник їх розігнав. “Куліш чоловік дуже трудящий, я його люблю!” Як сказав він таке, то вони й попіджали хвости. Звелів, щоб і не озивались більш про ті брехні, що на мене Катков і інші такі повидумували ${ }^{12}$.

Олександра Куліш все життя дуже болісно ставилася до критики, спрямованої проти іiї чоловіка.

Куліш переписувався з Номисом, запрошував його з сім'єю відвідати їх у Варшаві. Інколи у листах зустрічаються і приписки його дружини, адресовані або сестрі Надії, або ії чоловікові. Як правило, це були приписки побутового характеру. Так у листі Пантелеймона Куліша від 13 березня 1868 року є приписка Олександри Куліш: “Мы теперь скромнее живем: гостей мало бывает, а вечеров никаких. А в августе судьба наша кончится..."”. I продовжує: “Як неудача, то позабиравши свої злидні - на Піддубень...”"14. (Піддубень - назва хутора, який Куліш заснував недалеко від Мотронівки).

12 Лист П. Куліша від 15 серпня 1867 року до М. Т. Симонова (Номиса), ІР НБУВ, ф. 315, № 27.

13 Лист П. Куліша від 13 березня 1868 року до М. Т. Симонова (Номиса), ІР НБУВ, ф. 315, № 29.

14 Там само. 
Зв’язки 3 польською культурою не обмежувалися лише перебуванням у Варшаві і спілкуванням із тамтешніми культурними діячами. Ці культурні зв’ язки формувалися ще на Україні. На початку 40-х років Пантелеймон. Куліш познайомився 3 польським письменником, літературним критиком і публіцистом, істориком, представником “української школи” в польській літературі, автором повістей з українського життя Міхалом Грабовським (1804-1863). 3 Грабовським він познайомився в липні 1843 року. Куліш неодноразово бував у його маєтку Олександрівці на Чигиринщині.

Час, проведений у Грабовського, Куліш згадував як найщасливіший. Він писав:

Пізнав у Грабовському справдешнього писателя, писателя з талантом. Народні легенди, традиції про гайдамак і всяке інше добро, що назбирав Куліш у Київщині, - всім тим любовав Грабовський яко артист і піднімав угору дух молодому писателеві ${ }^{15}$.

Завдяки Грабовському він отримав доступ до польських матеріалів до історії України. Грабовський же познайомив Куліша із Свідзінським, знаним бібліофілом.

Перебуваючи у Грабовського, Куліш написав твір Україна. Це історична хроніка у віршах (повна назва Україна. Од початку Вкраїни до батька Хмельницького). Твір стилізовано під українські народні думи. Пантелеймон Куліш зробив спробу відтворити багатовікову історію України. Твір залишився незавершеним. Український письменник читав Україну письменнику польському. Міхалу Грабовському дуже подобалося. Куліш згадує:

Слухав він літніми ночами читання Кулішевого, - i так йому дещо подобалось, що, було, припинить його: "Постривайте: побіжу жінці скажу, який се гарний образ!” Деякі вийми з “України” списав він і послав був Крашевському у його “Atheneum”, да той не зваживсь напечатать, щоб, мовляв, “nie narazić się naszej publiczności”"16.

У Куліша і Грабовського були спільні творчі плани. Вони прагнули о3найомити свій народ із літературою другого народу. У листі від 24 грудня 1844 року Грабовський писав Кулішеві:

Статья моя о Пушкине может быть любопытна для вашей публики как доказательство, что и у нас знают ваших писателей и что ничто нам не препятствует их справедливо ценить. Эти две статьи мои, о Гоголе и о Пушкине, могут служить вступлением к дальнейшему ознакомлению русских с нашею литературою, о котором Вы пишете. Меня очень занял проект по-

15 П. Куліш, Жизнь Куліша [в:] Той самий, Твори: в 2-х т., т. 1, Київ 1994, с. 244.

16 Там само, с. 244. 
мещения таких статей в «Современнике». О подобном предприятии я давно уже мечтаю, но мои мечтания не могли осуществиться, пока не восприял их человек, занимающий высокое место в Вашей литературе, разумею П[етра] А[лексеевича] Плетнева. Сообщал я этот проект и Скальковскому, и Добровскому (издателю «Варшавской Денницы»), но это было выше их сил; потому-то переезд Ваш в Петербург может составить особую эпоху; и если Вы действительно станете осуществлять свою идею, то я всеми силами буду Вам содействовать. Знакомство русских с польскою литературою было бы для них открытием нового света, о котором они и не думают ${ }^{17}$.

Крім того, Пантелеймон Куліш видав двотомні Записки о Южной $P y c u$. Було заплановане видання третього тому, деякі матеріали до нього мав готувати Грабовський (наприклад, універсал Остряниці з коментарями). Третій том так і не побачив світ.

Оточення Куліша дуже вплинуло на Ганну Барвінок. Вона в усьому фанатично підтримувала чоловіка, надихалась його ідеями і працями. Олександра Куліш, якщо і не знала Міхала Грабовського особисто, то принаймні з листів чоловіка мала змогу отримати інформацію і скласти уявлення про нього. Пантелеймон Куліш дуже жалкував, що Грабовський покинув літературну діяльність. У листі до дружини від 11 вересня 1856 року Куліш пише:

Описав би я тобі жизнь Грабовського, да багато треба писать. Покинув за домашніми хлопотами книжки і зробивсь паном. Гірко нам на його дивиться, i сам він у свойому господарстві сумує. Коли б Господь уберіг мене от такого упадку, щоб скінчити своє діло так, як почав, і не звестись не знать на що!.. А як подумаю про всякії свої тривоги, то і в мене волос на голові встає, що коли б справді не змарніти серцем і духом. Недоки чоловікові й бороться, коли встає перед ним щодня супротивна хвиля! О Господи! Спаси потопающих і постав їх нозі на правоті Твоїй ${ }^{18}$.

І у листі до Плетньова від 4 грудня 1856 року Куліш пише:

Был я у Грабовского, который променял литературу на сахароварство и строит дом, из которого выйдут очень живописные развалины ${ }^{19}$.

Грабовський до самої смерті листувався із Пантелеймоном Кулішем. Куліш дав йому таку оцінку, яка, очевидно, була сприйнята Ганною Барвінок:

Грабовський яко артист стояв вище свого товариства польського і його політичного погляду ${ }^{20}$.

17 В. Петров, Пантелеймон Куліш у п'ятдесяті роки, “Кур’єр Кривбасу” 2009, № 238239 (Вересень-жовтень), с. 277-278.

18 Там само, с. 307.

19 Там само.

20 Там само, с. 244. 
У 1882 році у Львові Пантелеймон Куліш видає публіцистичну брошуру Крашанка русинам і полякам на Великдень 1882 року. Він прагнув надихнути на співпрацю українську і польську інтелігенцію. Автор брошури закликав український і польський народ забути давні чвари. Одним iз його тверджень було те, що козацькі повстання і війни проти шляхти (української і польської) - то виступи "руїнників" проти “культурників" і що добиватися незалежності України від Речі Посполитої треба було мирним, просвітительським шляхом. Традиційно козаків зображали як благородних героїв, як захисників рідного краю. Куліш же поглянув на козацтво польськими очима: козаки - руйнівна, неконтрольована стихія. Співвітчизникам Куліша не сподобалася ця дегероїзація козацтва. У середовищі польської інтелігенції брошурою зацікавилися. Автора стали запрошувати на свої зібрання.

Полемічною відповіддю на працю Пантелеймона Куліша Крашанка русинам і полякам на Великдень 1882 року була брошура Данила Мордовця За крашанку - писанка. П. Ол. Кулішеві (1882), в якій, визнаючи заслуги Пантелеймона Куліша, автор піддав критиці осудження ним селянсько-козацьких повстань, приниження ролі народних мас в історії України. 3 критикою Куліша виступили також Іван Франко та Микола Костомаров. Вони критикували його за дегероїзацію козацтва, піднесення української дрібної шляхти, міщан і польської шляхти. Ганна Барвінок завжди виступала захисником свого чоловіка.

Ганна Барвінок ніколи не прагнула бути на перших ролях ні в сімейному житті, ні в українській літературі. Власне життя вона присвятила своєму чоловікові, ставлячи його інтереси і літературну діяльність на перше місце. Ганна Барвінок все життя друкувалася по журналах та альманахах, лише в 1902 році український письменник і громадський діяч Борис Грінченко видав перший збірник оповідань письменниці (Оповідання з народних уст). Ганна Барвінок в першу чергу етнограф, а вже потім майстер художнього слова. Оповідання, як літературний жанр, письменниця використовує для подачі записаного “із народних вуст” фольклорного матеріалу, побутових замальовок, передачі живої народної мови, якою говорять іiї героїні, та й вона сама. Слова із оповідань Ганни Барвінок Борис Грінченко використав у своєму Словарі української мови (1907-1909).

Що до літературного процесу, то іiі дуже хвилювала незначна кількість жінок-письменниць в українській літературі. Іноді вона навіть докоряла українкам за їх інертність. У листі від 25 листопада 1901 року до Бориса Грінченка Ганна Барвінок нарікала:

Чого українки такі мовчазні? Уже й народ ворушиться, пише дехто і так понаписував, що і в «Щирі Сльози» не можна помістить - безграмотно і непоетично. А наші інтелігентні українки мовчать. Чи вже ж він для їх не писав, про їх не журивсь? А Ваша дружина (йдеться про Марію Загірню - Т. О.) 
як владіє пером - і не хоче однієї сльози проронить... Довго ще наша Україна буде німа!.. Треба ж комусь початок зробить. Вовчок, я вийшли перші з своїми оповіданнями, хоч я і несміливо, а тепер скільки письменниць!.. Да і Вовчок спершу несміло, а моя дружина підбодрила, злаштувала ${ }^{21}$.

І в той же час Ганні Барвінок дуже не подобалось, коли ії порівнювали з Марком Вовчком. Особливо Олександру Куліш ображало, що Марка Вовчка називали першою українською письменницею, а Ганну Барвінок - iii ученицею. Такі твердження вона категорично спростовувала. Натомість письменниця завжди підкреслювала свою першість, наголошуючи, що вона "не доїхавши ще до Варшави, зробилась письменницею"22. У одному із листів до Бориса Грінченка Ганна Барвінок звертає увагу:

Чи Ви завважили, що Г[анна] Барвінок із жіноцтва перша виступила на літературне поприще? А потім уже Вовчок. Да і хто його знає, і тепер двояко толкують, чи то вона, чи то чоловік ії писав? Суміння бере, щоб московка так швидко оволоділа знанням нашої мови, нравів, звичаїв. Д[обродій] Жемч[ужников] і довго вештався по Україні - i тож багато помилявся. А тож і надила до себе молодиць, іще й їй горем хвалилися... хто його знає. У нас і свої до ладу не знають і не хочуть знати. Я думаю, між паперами іiї дружини були ж чорнові рукописі ${ }^{23}$.

В листі до Грінченка від 11 грудня 1905 року вона пише: “Ще ж треба сказати, що і стареньку бабусю Г[анну] Барвінок забули. А вона ж перша одкрила шлях до писання - перша 3 жіноцтва почала"24. I найбільше Ганна Барвінок пишалася словами М. Костомарова, переданими ій братом Василем. Ці слова письменниця наводить у листі від 4 квітня 1900 року:

Одного разу вбіг до мене Костомаров, мов несамовитий, та й кричить: “Знаете ли, что за талант у Алекс[андры] Мих[айловны]! Удивительный!.. Она выше Марка Вовчка!.. И язык у неё лучше, искреннее, проще, - и народ изображает вернее!"25.

Варшава - місто знакове для Ганни Барвінок. Дорога до Варшави, перебування у Варшаві у товаристві Куліша і його оточення виявилися дорогою в українську літературу. Олександра Білозерська-Куліш стала однією із перших жінок-письменниць, основоположницею етнографічного реалізму в літературі. Дорогою, виконуючи настанови чоловіка і записуючи все, що бачить, вона збирала матеріал для своїх оповідань. I лише

21 Лист до Б. Д. Грінченка від 1902 року (?), ІР НБУВ, ф. ІІІ, № 37983.

22 Г. Барвінок, Приїзд до Києва на перепутті до Вариави, "Українська хата” 1911, Липень-серпень, с. 307.

23 Лист до Б. Д. Грінченка від 1902 року (?), IP НБУВ, ф. III, № 37983.

24 Лист до Б. Д. Грінченка від 11 грудня 1905 року, ІР НБУВ, ф. ІІІ, № 37954.

25 Лист до Б. Д. Грінченка від 4 квітня 1900 рокут ІР НБУВ, ф. III, № 38095. 
об’єктивні обставини (арешт чоловіка, клопотання за нього, заслання до Тули, куди Олександра Куліш поїхала разом із чоловіком) затримали появу в літературі нового імені - Ганна Барвінок. У Варшаві служив її брат Помпей, були знайомі П. Куліша, які підтримали у скрутну хвилину. У Варшаві ж заарештували ії чоловіка і брата. Цей арешт докорінно змінив життя Олександри Куліш. Проте зв'язки Ганни Барвінок з польським культурним середовищем не обмежувалися лише перебуванням певний час у певному географічному місці. Вони формувалися завдяки Кулішу і через його посередництво.

\section{ЛІТЕРАТУРА}

Barvinok Anna. 1861. S Volyni. “Osnova”. Ânvar': 283-292 [Барвинок Анна. 1861. C Boльни. “Основа". Январь: 283-292].

Barvìnok Ganna. 1902. Židivs'kij kripak. V: Barvìnok G. Opovidannâ z narodnih ust. Kiïv: 18-30 [Барвінок Ганна. 1902. Жидівський кріпак. В: Барвінок Г. Оповідання з народних уст. Київ: 18-30].

Barvìnok Ganna. Prï̈zd do Kiêva na pereputtì do Varšavi. "Ukraïns'ka hata" 1911. Lipen'serpen': 303-317 [Барвінок Ганна. Приїзд до Києва на перепутті до Варшави. "Українська хата" 1911. Липень-серпень: 303-317].

Grìnčenko Boris. 2001. Poet žinočogo gorâ O. M. Kulǐševa. V: Barvìnok Ganna. Zbirnik. Do 170-rǐččâ vìd dnâ narodžennâ. Red. Šenderovs'kij V. Kiïv: Rada: 374-388 [Грінченко Борис. 2001. Поет жіночого горя О. М. Кулішева. В: Барвінок Ганна. Збірник. До 170-річчя від дня народження. Ред. Шендеровський В. Київ: Рада: 374-388].

Kuliš Pantelejmon. 1994. Žizn' Kulǐša. V: Kuliš P. Tvori: v 2-h t. T. 1. Kiïv: Naukova dumka: 234-264 [Куліш Пантелеймон. 1994. Жизнь Куліша. В: Куліш П. Твори: в 2-х т. Т. 1. Київ: Наукова думка: 234-264].

List do B. D. Grinčenka (kinec' bereznâ - počatok kvitnâ 1900 roku). V: IR NBUV, f. III, $\mathrm{nr} 38094$ [Лист до Б. Д. Грінченка (кінець березня - початок квітня 1900 року). В: IP НБУВ, ф. III, № 38094].

List do B. D. Grìnčenka vid 11 grudnâ 1905 roku. V: IR NBUV, f. III, nr 37954 [Лист до Б. Д. Грінченка від 11 грудня 1905 року. В: ІР НБУВ, ф. III, № 37954].

List do B. D. Grìnčenka vìd 11 travnâ 1900 roku. V: IR NBUV, f. III, nr 38100 [Лист до Б. Д. Грінченка від 11 травня 1900 року. В: ІР НБУВ, ф. III, № 38100].

List do B. D. Grìnčenka vìd 12 lipnâ 1900 roku. V: IR NBUV, f. III, nr 38107 [Лист до Б. Д. Грінченка від 12 липня 1900 року. В: ІР НБУВ, ф. III, № 38107].

List do B. D. Grìnčenka vid 1902 roku (?). V: IR NBUV, f. III, nr 37983 [Лист до Б. Д. Грінченка від 1902 року (?). В: IP НБУВ, ф. III, № 37983].

List do B. D. Grìnčenka vid 25 listopada 1901 roku. V: IR NBUV, f. III, nr 38035 [Лист до Б. Д. Грінченка від 25 листопада 1901 року. В: ІР НБУВ, ф. III, № 38035].

List do B. D. Grìnčenka vìd 4 kvitnâ 1900 roku. V: IR NBUV, f. III, nr 38095 [Лист до Б. Д. Грінченка від 4 квітня 1900 року. В: ІР НБУВ, ф. ІІІ, № 38095].

List P. Kulǐša vìd 13 bereznâ 1868 roku do M. T.Simonova (Nomisa). V: IR NBUV, f. 315 , $\mathrm{nr} 29$ [Лист П. Куліша від 13 березня 1868 року до М. Т. Симонова (Номиса). В: IP НБУВ, ф. 315, № 29]. 
List P. Kuliša vìd 15 serpnâ 1867 roku do M. T. Simonova (Nomisa). V: IR NBUV, f. 315, nr 27 [Лист П. Куліша від 15 серпня 1867 року до М. Т. Симонова (Номиса). В: IP НБУВ, ф. 315, № 27].

Petrov Viktor. 2009. Pantelejmon Kuliš u p âtdesâtì roki. "Kur'êr Krivbasu" 2009 nr 238239: 241-309 [Петров Віктор. 2009. Пантелеймон Куліш у п'ятдесяті роки. “Кур’єр Кривбасу” 2009 № 238-239: 241-309].

\title{
WARSAW IN THE LIFE AND WORK OF HANNA BARVYNOK
}

\begin{abstract}
Hanna Barvynok (Oleksandra Mykhailivna Bylozerska-Kulish, 1828-1911) is one of the pioneer female writers in the history of Ukrainian literature. In the contest for the primacy she can challenge even Marco Vovchok, who is traditionally recognized as the first Ukrainian female writer. There was a time when Hanna Barvynok was well-known and popular, but today her legacy is given much less attention than it deserves.

Known mostly as Oleksandra Kulish, she remained in the shadow of fame of her brilliant and respected husband Panteleimon Kulish, becoming not only his wife but also a devoted friend, helper and adherent, and not focusing on her own literary talent. Only a will to help and being worthy of her prominent husband encouraged her to literature activity.

Warsaw became a significant place for Oleksandra Kulish. Trip to Warsaw, staying in Warsaw along with Kulish and his friends became a path to Ukrainian literature for Oleksandra Kulish. This very experience turned her into a female pioneer and innovator Hanna Barvynok.

Hanna Barvynok becomes a founder of a new style in Ukrainian literature - ethnographic realism. Fulfilling her husband's recommendations and writing down everything she saw travelling from Chernigov region to Warsaw, she vividly described realities of the time, gathering material for her first short stories. There is no doubt that the cultural environment Hanna Barvynok lived in, as well as her brother's and husband's Polish circle of friends made a significant influence on the beginning writer. Warsaw not only inspired her to write but also drastically changed the life of Hanna Barvynok. But Hanna Barvynok's connections with Polish cultural environment were not limited by her temporary stay in certain geographical area. They were developing because of Kulish and through his influence.
\end{abstract}

All her life Hanna Barvynok repeated that she just «writes down the common people's words», as she was taught by her husband - P. O. Kulish. Only subjective conditions (Kulish's arrest, her worries about his fate, his deportation to Tula, her decision to follow her husband) delayed the appearance of the new name in Ukrainian literature - Hanna Barvynok.

Keywords: Hanna Barvynok, Panteleimon Kulish, Polish cultural connections, ethnographic realism, Ukrainian literature, founder.

\section{WARSZAWA W ŻYCIU I TWÓRCZOŚCI HANNY BARWINOK}

Streszczenie: Niniejszy artykuł poświęcony jest Hannie Barwinok (Ołeksandra Biłozerska-Kulisz, 1828-1911), jednej z pierwszych pisarek ukraińskich, która zadebiutowała niemal równocześnie z inną pisarką, tworzącą pod pseudonimem Marko Wowczok. Waż- 
nym miejscem w kształtowaniu pisarskiej osobowości przyszłej literatki była Warszawa, gdzie przebywała, towarzysząc swemu mężowi, Pantełejmonowi Kuliszowi.

Zdaniem Autorki, Hanna Barwinok jest jednym z fundatorów nowego nurtu w literaturze ukraińskiej, zwanego realizmem etnograficznym. Podczas swej podróży z Czernihowszczyzny do Warszawy wykonała zalecenia męża, aby zapisywać i opisywać wszystko to, co widzi, zbierając tym samym materiał do przyszłych utworów literackich. Jest przy tym zrozumiałe, że środowisko kulturalne, w którym naówczas przebywała Hanna Barwinok, a także polskie otoczenie jej brata oraz jej męża, nie mogło pozostać bez wpływu na początkującą pisarkę.

Slowa kluczowe: Hanna Barwinok, Pantełejmon Kulisz, polskie związki kulturowe, realizm etnograficzny, literatura ukraińska. 